\title{
Effect of Nitrogen Levels and Its Time of Application on Yield Attributes, Yield and Economics of Barley (Hordeum vulgare L.)
}

\author{
Srimannarayan Dubey, Ankit Tiwari*, Vivek Singh, \\ Vinay Kumar Pandey and Ghanshyam Singh
}
Department of Agronomy, N. D. University of Agriculture and Technology, Kumarganj, Faizabad, (UP) - 224 229, India

*Corresponding author

\begin{tabular}{|c|}
\hline Keywords \\
\hline $\begin{array}{l}\text { Barley, Nitrogen } \\
\text { levels, Time of } \\
\text { application, Yield, } \\
\text { Economics }\end{array}$ \\
\hline Article Info \\
\hline $\begin{array}{l}\text { Accepted: } \\
\text { 14 December } 2017 \\
\text { Available Online: } \\
\text { 10 January } 2018\end{array}$ \\
\hline
\end{tabular}

Barley (Hordeum vulgare L.) is one of the world's fourth most important cereals after wheat, rice and maize. In India, it is popularly

\section{A B S T R A C T}

An investigation was conducted in rabi season of 2013-14to work out the economics of various treatment combinations in barley crop. The experiment was laid out in split plot design with four levels of nitrogen $\left(0,20,40\right.$, and $\left.60 \mathrm{~kg} \mathrm{~N} \mathrm{ha}^{-1}\right)$ and three time of application ( $(1 / 2$ at the time of sowing and $1 / 2$ after first irrigation, $1 / 3$ at sowing and $2 / 3$ after first irrigation, $1 / 3$ at sowing, $1 / 3$ after first irrigation and $1 / 3$ after second irrigation) with three replications. Nitrogen level $\left(60 \mathrm{kgha}^{-1}\right)$ and Time of application $(1 / 3$ at sowing and $2 / 3$ after first irrigation) treatment was found significantly superior over rest of the treatments in yield attributing characters and yield i.e. No. of spikelets spike ${ }^{-1}$, Length of spike $(\mathrm{cm})$, No. of grains spike ${ }^{-1}$, Test weight $(\mathrm{g})$, Grain and Straw yield $\left(\mathrm{qha}^{-1}\right)$ and Harvest index $(\%)$. Treatment $\mathrm{N}_{3}\left(60 \mathrm{kgha}^{-1}\right)$ increases significantly over other rest treatments and was found superior with No. of spikelets spike ${ }^{-1}(9.48)$, Length of spike $(8.94 \mathrm{~cm})$, No. of grains spike ${ }^{-1}(26.88)$, Test weight $(42.69 \mathrm{~g})$, grain yield $\left(24.52 \mathrm{qha}^{-1}\right)$ and straw yield $\left(37.60 \mathrm{qha}^{-1}\right)$ under main plot treatments. Treatment $\mathrm{T}_{2}(1 / 3$ at sowing and $1 / 3$ after first irrigation and $1 / 3$ after second irrigation) was found best with No. of spikelets spike ${ }^{-1}(8.90)$, Length of spike $(8.11 \mathrm{~cm})$, No. of grains spike ${ }^{-1}(24.09)$, Test weight $(41.90 \mathrm{~g})$, grain yield $\left(21.96 \mathrm{qha}^{-1}\right)$ and straw yield $\left(32.46 \mathrm{qha}^{-1}\right)$ as compared to other treatments and being at par with Treatment $T_{3}(1 / 3$ at sowing and $1 / 3$ after first irrigation and $1 / 3$ after second irrigation) in all aspects of yield attributes and yield. Highest net return of Rs. $23593.88 \mathrm{ha}^{-1}$ was recorded with $\mathrm{N}_{3} \mathrm{~T}_{2}\left(60 \mathrm{~kg} \mathrm{~N} \mathrm{ha}^{-1}\right)+$ Time of application (1/3 at sowing and $2 / 3$ after first irrigation) $f b$ Rs. 19836.88 ha $^{-1}$ with $\mathrm{N}_{3} \mathrm{~T}_{3}(60$ $\left.\mathrm{kg} \mathrm{N} \mathrm{ha}{ }^{-1}\right)+$ Time of application (1/3 at sowing, 1/3 after first irrigation and $1 / 3$ after second irrigation) treatment combination. The b-c ratio (Rs. 1.04) was observed maximum under the treatment combination of $\mathrm{N}_{3} \mathrm{~T}_{2} f b$ (Rs. 0.87) $\mathrm{N}_{3} \mathrm{~T}_{3}$ treatment combination.

\section{Introduction}

known as "Jau." India is on $7^{\text {th }}$ ranks in the world in respect to total area and production. In India, barley crop was grown over an area of 695.0 thousand hectare with a production of 1743.2 thousand tones and productivity of 
$25.10 \mathrm{qha}^{-1}$ during 2012-13 (Anonymous, 2013). Uttar Pradesh is one of the most important barley growing states of India. In Uttar Pradesh, the area under cultivation of barley is about 168.0 thousand $\mathrm{ha}^{-1}$ with a production of 441.0 thousand tones and productivity of $26.3 \mathrm{qha}^{-1}$ (Anonymous, 2013). Half of the total area under this crop is irrigated and rest remains rainfed. This crop has wider adoptability and needs less water and it is more tolerant to salinity and other stress conditions. Therefore, it is of great significance in areas where successful wheat crop cannot be grown due to unsuitable soil and insufficient irrigation.

Barley is very sensitive to insufficient nitrogen and very responsive to nitrogen fertilization. The most important role of nitrogen in the plant is its presence in the structure of protein and nucleic acids, which are the most important building and formative substances from which the living material or protoplasm of every cell is made. In addition, nitrogen is also found in chlorophyll, the green coloring matter of plants.

Excessive nitrogen causes excessive vegetative growth, resulting in greatly increased danger of lodging, delayed maturity and greater susceptibility to diseases and pests. Nitrogen application at proper dose has the most important effect in terms of increasing crop production. Farmers use nitrogen fertilizers indiscriminately without adequate information concerning actual soil requirements.

Nitrogen is a key factor in achieving an optimum yield in cereals and in their growing period requires lot amount of absorbed nitrogen. Proper dose of nitrogen increased leaf area, tillers formation, leaf area index and leaf area duration and this increase led to much greater production of dry matter and grain yield.
Seeding of barley is generally done in early November to late December. Late harvesting of preceding crops, excessive soil moisture after rainy season and increasing cropping intensity have pushed a sizable barley area under moderately late to late sown condition. Late sown plants experience low temperature at the vegetative stage, which decrease the physiological processes particularly, root growth and nutrient and water uptake. On the contrary, reproductive stage of late sown plants experience high temperature, which reduces grain growth and ultimately crop productivity. There are few options regarding fertilizer requirement of late planted barley. Some argue for higher level of nutrient to the crop to compensate yield loss owing to delayed seeding (Kotrba et al., 1984), others advocate lower level of nutrient as the crop is unable to absorb higher level of nutrient owing to its reduced growth duration (Kahnt and Kubler, 1981).

To get maximum benefit from the fertilizer use the fertilizer should not only be applied in optimum quantity but also at right time as timely nitrogen application in one agronomic technique which has helped considerably in increasing the nitrogen use efficiency (NUE).It is now very well established that for most crops nitrogen must be applied in two or three split doses coinciding with the crop growth stages when its requirement is high therefore, it is high time to assess the effect of optimum dose of nitrogen and its time of application to increase the fertilizer use efficiency in barley.

Thus, nitrogen fertilization strategies must be so tuned as to balance the often contradicting goal of maximum production with desirable protein content in grain. Method of split application of nitrogen, to meet the crop requirement throughout life cycle for higher production and less accumulation of nitrogen in grain, may be one of the strategies to 
achieve the high yield and quality of barley for malting industries. However, little work has been done on this aspect of effect of time and levels of nitrogen application on late sown barley. Keeping all above facts in view the present study was undertaken to work out the economics of various treatment combinations in barley crop.

\section{Materials and Methods}

The present investigation was under taken during rabi 2013-14 at the Agronomy Research Farm of Narendra Deva University of Agriculture and Technology, Kumarganj, Faizabad. The experimental site falls under subtropical climate in Indo-Gangetic plains having alluvial calcareous soil and lies between $26^{\circ} 47^{\prime}$ North latitude and $82^{\circ} 12^{\prime}$ East longitude at an altitude of $113 \mathrm{~m}$ from mean sea level. The region receives annual rainfall ranging from $1000-1200 \mathrm{~mm}$ and 90 per cent of which is received in Mid-June to end of September. The soil of the experimental field

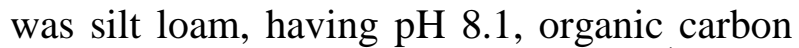
0.38 , available $\mathrm{N}, \mathrm{P}$ and $\mathrm{K} 185.0 \mathrm{kgha}^{-1}, 15.25$ $\mathrm{kgha}^{-1}$ and $265.0 \mathrm{kgha}^{-1}$ respectively. The seeds were sown at proper moisture on $29^{\text {th }}$ December 2013 of variety Narendra Barley 1. Sowing was done in rows $20 \mathrm{~cm}$ apart and $4 \mathrm{~cm}$ deep in furrow with desi plough. A certified seed was used at the rate of $100 \mathrm{~kg} \mathrm{ha}{ }^{-1}$. There were twelve treatment combinations as detailed below:

The experiment was laid out in split plot design with four levels of nitrogen $(0,20,40$, and $60 \mathrm{~kg} \mathrm{~N} \mathrm{ha}^{-1}$ ) and three time of application $(1 / 2$ at the time of sowing and $1 / 2$ after first irrigation, $1 / 3$ at sowing and $2 / 3$ after first irrigation, $1 / 3$ at sowing and $1 / 3$ after first irrigation and $1 / 3$ after second irrigation) with three replications. Main plot consists of four Nitrogen levels, i.e. $\mathrm{N}_{0}: \mathrm{N}$ Level $\left(0 \mathrm{kgha}^{-1}\right)$, $\mathrm{N}_{1}$ : NLevel $\left(20 \mathrm{kgha}^{-1}\right), \mathrm{N}_{2}$ : NLevel $(40 \mathrm{~kg}$ $\left.\mathrm{ha}^{-1}\right), \mathrm{N}_{3}: \mathrm{N}$ Level $\left(60 \mathrm{kgha}^{-1}\right)$ and sub plot consists of three Time of application, i.e. $\mathrm{T}_{1}$ : Half at the time of sowing and half after first irrigation, $\mathrm{T}_{2}$ : One third at sowing and two third after first irrigation and $\mathrm{T}_{3}$ : One third at sowing and one third after first irrigation and one third after second irrigation.

Numbers of grains from three selected spikes were counted and average was worked out on the basis of single spike. Length of five selected spikes from each plot was measured carefully from the neck node to the tip of last grain and averaged out to get the length of single spike. The total number of grain of five selected spikes were counted and averaged to get the number of grains per spike. One thousand grains from net plot was counted and weighed to get 1000 grains weight (g).After measuring the bundle weight of the harvested produce of each net plot, the grains were separated by threshing. The grains thus obtained were air dried to maintain $12 \%$ moisture and grain yield were recorded in $\mathrm{kg}$ plot $^{-1}$ which was further multiplied with conversion factor in order to get in $\mathrm{q} \mathrm{ha}^{-1}$. The weight of the grains were subtracted from the weight of total harvested produce of each net plot to get the straw yield in $\mathrm{kg}_{\text {plot }}{ }^{-1}$ which was further multiplied with the conversion factor in order to get straw yield in $\mathrm{q} \mathrm{ha}^{-1}$. The recovery of the grains in the total harvested produce expressed as harvest index. It was calculated with the help of following formula.

Harvest index $(\%)=\frac{\text { Grain yield }}{\text { Total biomass yield }} \times 100$

\section{Results and Discussion}

The data on yield attributing characters and yield increased significantly with $\mathrm{N}_{3}$ : $\mathrm{N}$ level $\left(60 \mathrm{kgha}^{-1}\right)$ under main plot and $\mathrm{T}_{2}$ : One third at sowing and two third after first irrigation under sub plot during course of investigation. Number of spikelets spike $^{-1}$ influenced by varying nitrogen levels and there time of 
application has been presented in Table 1. The number of spikelets spike ${ }^{-1}$ was significantly affected by various nitrogen levels. Maximum number of spikelets was recorded with $60 \mathrm{~kg}$ $\mathrm{N} \mathrm{ha}^{-1}$ which was significantly higher than rest of the treatments. The time of nitrogen application had significant effect on the number of spikelets spike ${ }^{-1}$. It was recorded maximum under $T_{2}$ (1/3 at sowing and 2/3 after first irrigation) treatment showing its significant superiority over other treatment, except $T_{3}$ treatment $(1 / 3$ at sowing and $1 / 3$ after first irrigation and $1 / 3$ after second irrigation). The data pertaining to length of spike of barley as influenced by different nitrogen levels and their time of application are presented in Table 1 and depicted in Figure 1. Maximum spike length was recorded with $60 \mathrm{~kg} \mathrm{~N} \mathrm{ha}^{-1}$ showing its significant superiority over the rest of treatments. The time of nitrogen application had significant effect on the length of spike. It was recorded significantly higher under $\mathrm{T}_{2}$ treatment as compared to other treatments. However, shortest length of spike was observed in $T_{1}$ treatment where nitrogen was applied $1 / 2$ at sowing and $1 / 2$ after first irrigation. Number of grains spike $^{-1}$ as influenced by varying nitrogen levels and its time of application have been presented in Table 1. The maximum number of grains spike ${ }^{-1}$ was recorded with 60 $\mathrm{kg} \mathrm{N}$ ha $^{-1}$ showing its significant superiority over other treatments. The time of application had significant effect on the grains spike ${ }^{-1}$. It was recorded maximum under $T_{2}(1 / 3$ at sowing and $2 / 3$ after first irrigation) treatment showing its significant superiority over other treatments. The data pertaining to 1000 -grain weight (test weight) have been given in Table 1 and also depicted in Figure 1. A cursory glance over the data revealed that various nitrogen levels and its time of application did not influence 1000-grain weight. Maximum test weights were recorded with $60 \mathrm{~kg} \mathrm{~N} \mathrm{ha}^{-1}$ which was at par with other levels of nitrogen. The time of nitrogen application also did not affect the test weight significantly. Maximum test weight was recorded with $T_{2}(1 / 3$ at sowing and $2 / 3$ after first irrigation) treatment followed by $\mathrm{T}_{3}(41.10 \mathrm{~g})$ and $\mathrm{T}_{1}(40.30 \mathrm{~g})$, respectively. An inspection of data presented in Table 1 and Figure 1 revealed that increasing levels of nitrogen has positive correlation with yield and yield attributes viz., length of spike, number of spikelets spike ${ }^{-1}$, number of grain spike ${ }^{-1}$, test weight, grain yield and straw yield, which led to increase in yield can be discussed in the light of fact that availability of nitrogen in higher amount resulted in higher dry weight which ultimately increased the yield attributes and yield. The number of grains spike $^{-1}$ was affected by various nitrogen levels and its time of application. The maximum number of grains spike $^{-1}$ was recorded under $60 \mathrm{~kg} \mathrm{~N} \mathrm{ha}{ }^{-1}$ in comparison to lower nitrogen levels. The number of grains spike ${ }^{-1}$ determined primarily by the amount of nutrient observed and secondary by the amount of carbohydrate produced at the time of spikelets differentiation. The carbohydrates production has positive correlation with levels of nitrogen. Hence, under present study increase in the number of grains spike ${ }^{-1}$ might be due to better assimilation of carbohydrate in spike. Maximum length of spike, number of spikelets spike $^{-1}$ and test weight were recorded with 60 $\mathrm{kg} \mathrm{N}$ ha $^{-1}$ sowing its significant superiority over rest of the treatments. The lowest value of yield attributing characters were obtained under lowest nitrogen level because plants were subjected to utilize the least amount of available nitrogen which resulted into reduced translocation of photosynthesis from source to sink and thus led to poor growth and various yield attributing characters. Similar findings were reported by Diwedi et al., (1987), Singh and Singh (1997), Biswas and Singh (1982) in case of spike length, Kerich and Halloran (1996) in case of number of spikelets spike ${ }^{-1}$ and number of grain spike ${ }^{-1}$, Bark (1980), Prasad and Singh (1987) and Noworolink 
(1990) in case of test weight. Yield attributing characters are the resultant of vegetative growth of the plants. All the attributes viz. number of spikelets spike ${ }^{-1}$, length of spike, number of grains spike ${ }^{-1}$ and 1000- grains weight were affected significantly due to different time of nitrogen application. Highest value of all the yield attributes was recorded under $T_{2}$ treatment (1/3 at the time of sowing and $2 / 3$ after first irrigation) as compare to other treatments. This could possibly be due to continuous availability of nitrogen in plant at all the critical stages might have resulted in enhanced photosynthetic activities of leaves which increased the translocation of photosynthates from source of leaves and stem to the sink, leading to highest yield attributes under the $\mathrm{T}_{1}$ treatment, on the contrary nitrogen was applied as $1 / 2$ at the time of sowing and $1 / 2$ after first irrigation gave lowest indices of all the yield attributes as the lessavailability of nitrogen on later stages after germination under this treatment, has led to the poorer and lowest yield attributes. Similar results were obtained by Singh and Singh (2013) in case of number of grains spike ${ }^{-1}$ and Singh and Singh (2005) in case of test weight.

Data pertaining to grain yield of experimental crop of barley as affected by different levels of nitrogen and its time of application have been presented in Table 2 and depicted in Figure 2. It is quite evident from the data that significant variation in the grain yield was observed due to different nitrogen levels. Data revealed that yield increased successively with increase in nitrogen level from 0 to $60 \mathrm{~kg} \mathrm{~N} \mathrm{ha}^{-1}$. The yield was recorded significantly higher $(24.25$ $\mathrm{q} \mathrm{ha}^{-1}$ ) under $60 \mathrm{~kg} \mathrm{~N} \mathrm{ha}^{-1}$ as compared to rest of the treatments. Grain yield obtained at 60 and $40 \mathrm{~kg} \mathrm{~N}$ ha $^{-1}$ were higher by 41.55 and 36.50 per cent over $0 \mathrm{~kg} \mathrm{~N} \mathrm{ha}^{-1}$, respectively. The lowest yield was recorded (14.33 $\mathrm{qha}^{-1}$ ) under $0 \mathrm{~kg} \mathrm{~N} \mathrm{ha}{ }^{-1}$. Grain yield of barley was affected significantly due to different time of nitrogen application. The grain yield was obtained higher (21.96 q ha $\mathrm{q}^{-1}$ under $\mathrm{T}_{2}$ treatment $(1 / 3$ at sowing and $2 / 3$ after first irrigation) which was significantly superior over rest of the treatments. The grain yield obtained under $T_{2}$ (1/3 at sowing and $2 / 3$ after first irrigation) was higher by 16.53 per cent over the treatment where nitrogen was applied as $1 / 2$ at sowing $1 / 2$ after first irrigation $\left(\mathrm{T}_{1}\right)$.Data regarding to straw yield as affected by various nitrogen level and its time of application have been presented in Table 2 and depicted in Figure 2. It is quite evident from the data that various nitrogen levels had significant influence on straw yield. Data revealed that straw yield $\left(\mathrm{q} \mathrm{ha} \mathrm{h}^{-1}\right)$ increased with the increase in nitrogen levels from 0 to $60 \mathrm{~kg} \mathrm{~N} \mathrm{ha}{ }^{-1}$. Straw yield was recorded significantly higher $\left(37.60 \mathrm{qha}^{-1}\right)$ under $60 \mathrm{~kg}$ $\mathrm{N} \mathrm{ha}{ }^{-1}$ as compared to rest of the treatments. The straw yield of barley obtained at 60 and $40 \mathrm{~kg} \mathrm{~N}$ ha $^{-1}$ were higher by 43.53 and 36.36 per cent, respectively over $0 \mathrm{~kg} \mathrm{~N}^{-1}$ which produced the lowest straw yield (21.23 $\left.\mathrm{q} \mathrm{ha}^{-1}\right)$. The time of nitrogen application had significant variation on straw yield as it is clear from the data presented in Table 2 and depicted in Figure 2. Data given in Table indicate that straw yield was recorded significantly higher under $T_{2}$ treatment $(1 / 3$ at sowing and $2 / 3$ after first irrigation) as compared to rest of the treatments. The lowest straw yield of $27.17 \mathrm{q} \mathrm{ha}^{-1}$ was recorded under $\mathrm{T}_{1}$ treatment where nitrogen was applied $1 / 2$ at sowing and $1 / 2$ at first irrigation. The data pertaining to harvest index are presented in Table 2 and depicted in Figure 2. Data clearly indicate that harvest index was not varied at significant level due to various nitrogen levels. It is quite evident from the data that different time of nitrogen application had nonsignificant effect on harvest index. The maximum value of harvest index was recorded under $\mathrm{T}_{2}$ (1/3 at sowing and 2/3 after first irrigation) treatment. However, the lowest value of harvest index was recorded under $T_{1}$ treatment where nitrogen was applied as $1 / 2$ at 
sowing and $1 / 2$ after first irrigation. Different nitrogen levels and its time of application had influence on grain yield. In general, average yield of barley under late sown condition is poor due to less exploitation of potentialities of the crop. Reduction in yield is caused due to delayed emergence to maturity. Delayed emergence of crop and premature drying due to high temperature and hot desiccating winds during grain filling stage cause the forced maturity of late sown crop which ultimately resulted in the heavy reduction in whole biomass. The yield was recorded significantly higher under $60 \mathrm{~kg} \mathrm{~N} \mathrm{ha}^{-1}$ as compared to other treatments. This might be due to adequate nitrogen availability which contributed to increase dry matter accumulation. Productivity of a crop is collectively determined by vigour of the vegetative growth, development as well as yield attributes which is the result of better translocation of photosynthates from source of leaves and stem to the grains. Better vegetative growth coupled with high yield attributes resulted into higher grain yield in 60 $\mathrm{kg} \mathrm{N} \mathrm{ha}{ }^{-1}$. Reduced nitrogen supply as in case of rest of the treatment, recorded lowest yield due to both poor growth and yield attributes. Singh et al., (1969), Abrmova et al., (1974), Birch et al., (1977) and Nagrajan (199293).Grain yields of barley were significantly influenced by various time of nitrogen application.

Highest yield was obtained under $\mathrm{T}_{2}$ treatment (1/3 at the time of sowing and $2 / 3$ after first irrigation). The increase in grain yield under this treatment was mainly due to improvement in yield attributing characters and growth of crops. The grain yield as the result of growth and development through efficient assimilation and utilization of available nitrogen by the growing plants during the entire grand growth period. Growth in vegetative phase and development in reproductive phase determines the yield. Thus yield is the function of complex inter relationship of various yield components which is determined from the growth in vegetative phase and from its subsequent reflection in reproductive phase and hence, productivity of a crop determined collectively by vigour of the yield attributes and plant population per unit area. The lowest yield were recorded under the $T_{1}$ treatment, where nitrogen was applied $1 / 2$ at the time of sowing and $1 / 2$ after first irrigation which was possibly due to reduced translocation of carbohydrates from source leaves and stem to sink. Similar findings were reported by Singh and Singh (2005), Singh and Singh (2013).Straw yield was influenced significantly by rates and time of nitrogen application. Maximum straw yield was recorded under $60 \mathrm{~kg} \mathrm{~N} \mathrm{ha}^{-1}$. This may be probably due to higher density of tiller and increased rate of dry matter production. Similar findings were reported by Singh et al., (1983), Kumar and Singh (1998).Straw yield was also noted higher under $\mathrm{T}_{2}$ treatment $(1 / 3$ at the time of sowing and $2 / 3$ after first irrigation) which was mainly due to more dry matter accumulation per unit area as a result of better performance of vegetative growth caused due to efficient assimilation and absorption of nitrogen from the soil during entire period of growth, unlike the lowest straw yield was recorded in the treatment $T_{1}$ where nitrogen was applied as $1 / 2$ at the time of sowing and $1 / 2$ after first irrigation. The lowest yield in the $T_{1}$ treatment may be due to reduced translocation of carbohydrates from source leaves and stem to sink, which ultimately resulted in to poor dry matter accumulation. Similar finding were reported by Noworolink (1990) and Singh and Singh (2005).Harvest index of barley was not affected significantly due to different nitrogen levels and time of application. However, the performance was better in $T_{2}(1 / 3$ at the time of sowing and $2 / 3$ after first irrigation) treatment. 
Table.1 Effect of nitrogen levels and its time of application on yield Contributory characters of barley

\begin{tabular}{|l|c|c|c|c|}
\hline \multicolumn{1}{|c|}{ Treatments } & $\begin{array}{c}\text { Number of } \\
\text { spikelets spike }\end{array}$ & $\begin{array}{c}\text { Length of } \\
\text { spike (cm) }\end{array}$ & $\begin{array}{c}\text { Number of } \\
\text { grains spike }^{-1}\end{array}$ & $\begin{array}{c}\text { 1000-grain } \\
\text { weight }\end{array}$ \\
\hline Nitrogen levels $\left(\mathbf{k g ~ h a}^{-1}\right)$ & & & & \\
\hline $\left.\mathbf{N}_{\mathbf{0}}\right)$ & 6.63 & 6.15 & 18.62 & 38.80 \\
\hline $\mathbf{N}_{\mathbf{1}}$ & 7.70 & 7.12 & 21.52 & 40.60 \\
\hline $\mathbf{N}_{\mathbf{2}}$ & 8.60 & 7.97 & 24.14 & 42.30 \\
\hline $\mathbf{N}_{\mathbf{3}}$ & 9.48 & 8.94 & 26.88 & 42.69 \\
\hline $\mathbf{S E m} \pm$ & 0.24 & 0.21 & 0.68 & 1.17 \\
\hline $\mathbf{C D}(\mathbf{P}=\mathbf{0 . 0 5})$ & 0.85 & 0.74 & 2.35 & $\mathrm{NS}$ \\
\hline $\mathbf{T i m}_{\mathbf{1}}$ of application & & & & \\
\hline $\mathbf{T}_{\mathbf{1}}$ & 7.64 & 7.19 & 22.01 & 40.30 \\
\hline $\mathbf{T}_{\mathbf{2}}$ & 8.90 & 8.11 & 24.09 & 41.90 \\
\hline $\mathbf{T}_{\mathbf{3}}$ & 7.78 & 7.33 & 22.27 & 41.10 \\
\hline $\mathbf{S E m} \pm$ & 0.17 & 0.17 & 0.49 & 0.92 \\
\hline $\mathbf{C D}(\mathbf{P}=\mathbf{0 . 0 5})$ & 0.53 & 0.50 & 1.47 & $\mathrm{NS}$ \\
\hline
\end{tabular}

Where,

Main Plots: Nitrogen Levels

$\mathrm{N}_{0}$ : $\mathrm{N}$ level $\left(0 \mathrm{~kg} \mathrm{ha}^{-1}\right)$

$\mathrm{N}_{1}$ : N level $\left(20 \mathrm{~kg} \mathrm{ha}^{-1}\right)$

$\mathrm{N}_{2}: \mathrm{N}$ level $\left(40 \mathrm{~kg} \mathrm{ha}^{-1}\right)$

$\mathrm{N}_{3}$ : N level $\left(60 \mathrm{~kg} \mathrm{ha}^{-1}\right)$
Sub-plots: Time of Application

$\mathbf{T}_{\mathbf{1}}$ : Half at the time of sowing and half after first irrigation $\mathbf{T}_{2}$ : One third at sowing and two third after first irrigation $\mathbf{T}_{3}$ : One third at sowing and one third after first irrigation and one third after second irrigation

Table.2 Effect of nitrogen levels and its time of application ongrain yield, straw yield and harvest index

\begin{tabular}{|c|c|}
\hline Treatment & Grain yielc \\
\hline \multicolumn{2}{|l|}{ Nitrogen levels $\left(\mathrm{kg} \mathrm{ha}^{-1}\right)$} \\
\hline $\mathbf{N}_{0}$ & 14.3 \\
\hline $\mathbf{N}_{1}$ & 19.8 \\
\hline $\mathbf{N}_{2}$ & 22.5 \\
\hline $\mathbf{N}_{3}$ & 24.5 \\
\hline SEm \pm & 0.4 \\
\hline $\mathrm{CD}(\mathrm{P}=\mathbf{0 . 0 5})$ & 1.6 \\
\hline \multicolumn{2}{|l|}{ Time of application } \\
\hline $\mathrm{T}_{1}$ & 18.3 \\
\hline $\mathbf{T}_{2}$ & 21.9 \\
\hline $\mathbf{T}_{3}$ & 20.6 \\
\hline SEm \pm & 0.3 \\
\hline $\mathrm{CD}(\mathrm{P}=0.05)$ & 1.1 \\
\hline \multicolumn{2}{|c|}{ Where, } \\
\hline \multicolumn{2}{|c|}{ Main Plots: Nitrogen Levels } \\
\hline \multicolumn{2}{|c|}{$\mathbf{N}_{0}: \mathrm{N}$ level $\left(0 \mathrm{~kg} \mathrm{ha}^{-1}\right)$} \\
\hline \multicolumn{2}{|l|}{$\mathrm{N}_{1}: \mathrm{N}$ level $\left(20 \mathrm{~kg} \mathrm{ha}^{-1}\right)$} \\
\hline $\mathrm{N}_{2}: \mathrm{N}$ level $\left(40 \mathrm{~kg} \mathrm{ha}^{-1}\right)$ & \\
\hline
\end{tabular}

\section{Sub-plots: Time of Application}

$\mathbf{T}_{\mathbf{1}}$ : Half at the time of sowing and half after first irrigation $\mathbf{T}_{2}$ : One third at sowing and two third after first irrigation $\mathbf{T}_{3}$ : One third at sowing and one third after first irrigation and one third after second irrigation 
Table.3 Economics of various treatments combinations

\begin{tabular}{|c|c|c|c|c|c|c|}
\hline $\begin{array}{l}\text { Treatments } \\
\text { combination }\end{array}$ & $\begin{array}{l}\text { Grains yield } \\
\qquad\left(\mathbf{q} \mathbf{h a}^{-1}\right)\end{array}$ & $\begin{array}{l}\text { Straw yield } \\
\qquad\left(\mathbf{q} \mathbf{h a}^{1}\right)\end{array}$ & $\begin{array}{l}\text { Gross return } \\
\left(\mathrm{Rs} \mathrm{ha}^{-1}\right)\end{array}$ & $\begin{array}{c}\text { Cost of } \\
\text { cultivation } \\
\left.(\operatorname{Rs~ha})^{-1}\right)\end{array}$ & $\begin{array}{l}\text { Net return } \\
\left(\operatorname{Rs~ha}^{-1}\right)\end{array}$ & B-C ratio \\
\hline $\mathbf{N}_{0} \mathbf{T}_{1}$ & 14.33 & 21.23 & 24255 & 21530.29 & 2724.71 & 0.12 \\
\hline $\mathrm{N}_{0} \mathrm{~T}_{2}$ & 14.33 & 21.23 & 24255 & 21530.29 & 2724.71 & 0.12 \\
\hline $\mathbf{N}_{0} T_{3}$ & 14.33 & 21.23 & 24255 & 21530.29 & 2724.71 & 0.12 \\
\hline $\mathbf{N}_{1} \mathbf{T}_{1}$ & 19.05 & 26.66 & 31619 & 21917.19 & 9701.81 & 0.44 \\
\hline $\mathrm{N}_{1} \mathbf{T}_{2}$ & 21.05 & 29.59 & 34991 & 22017.19 & 12973.81 & 0.58 \\
\hline $\mathbf{N}_{1} \mathbf{T}_{3}$ & 19.50 & 29.26 & 33154 & 22117.19 & 11036.81 & 0.49 \\
\hline $\mathrm{N}_{2} \mathrm{~T}_{1}$ & 19.86 & 28.07 & 33074 & 22204.16 & 10869.84 & 0.48 \\
\hline $\mathbf{N}_{2} \mathbf{T}_{2}$ & 24.60 & 36.08 & 41492 & 22304.16 & 19187.84 & 0.86 \\
\hline $\mathbf{N}_{2} \mathbf{T}_{3}$ & 24.25 & 35.93 & 41047 & 22404.16 & 18642.84 & 0.83 \\
\hline $\mathrm{N}_{3} \mathrm{~T}_{1}$ & 21.70 & 33.66 & 37344 & 22491.12 & 14852.88 & 0.66 \\
\hline $\mathrm{N}_{3} \mathrm{~T}_{2}$ & 26.87 & 41.57 & 46185 & 22591.12 & 23593.88 & 1.04 \\
\hline $\mathrm{N}_{3} \mathrm{~T}_{3}$ & 25.00 & 37.57 & 42528 & 22691.12 & 19836.88 & 0.87 \\
\hline
\end{tabular}




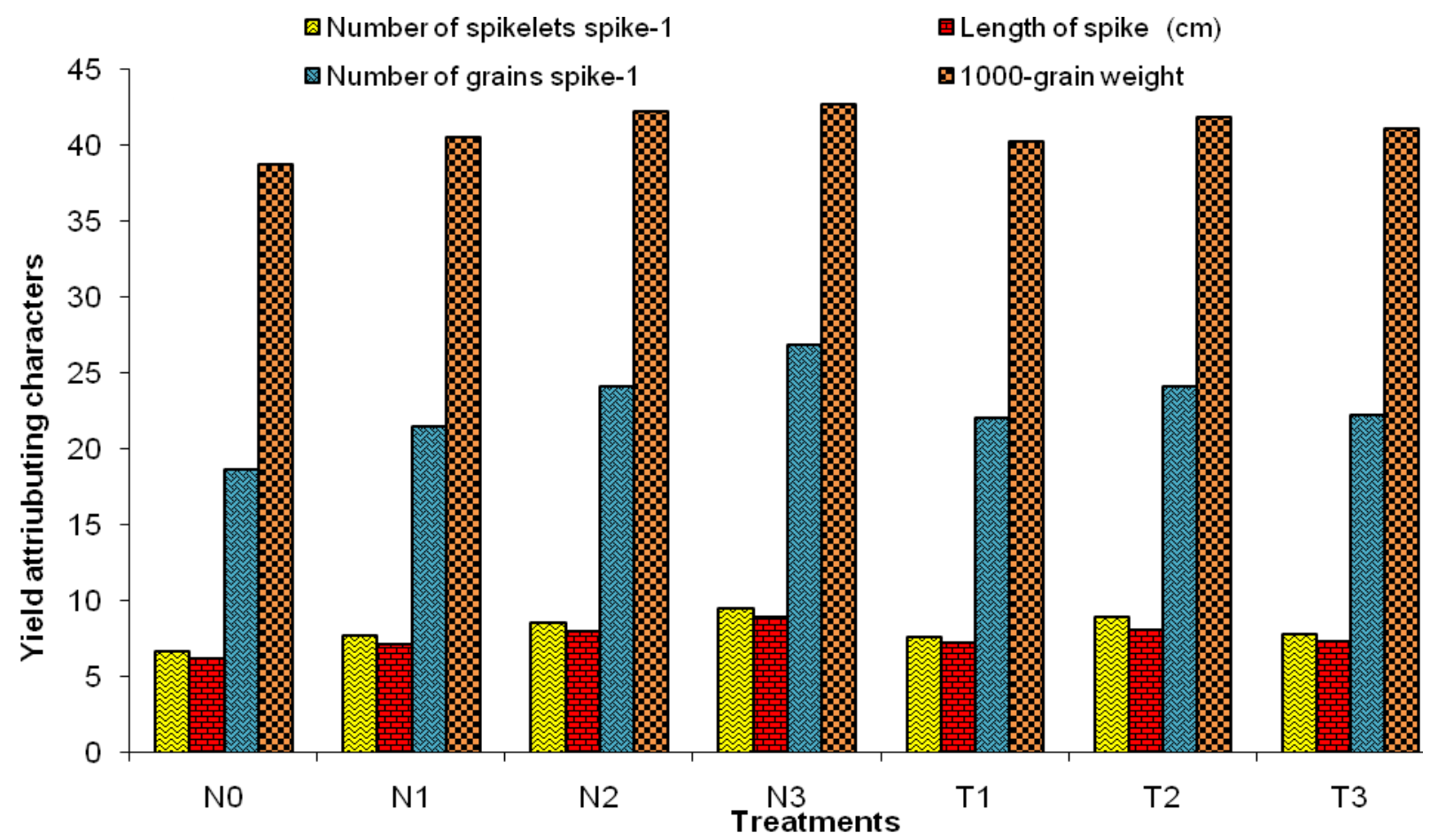

Fig. 1:Effect of nitrogen levels and its time of application on yield contributory characters of barley

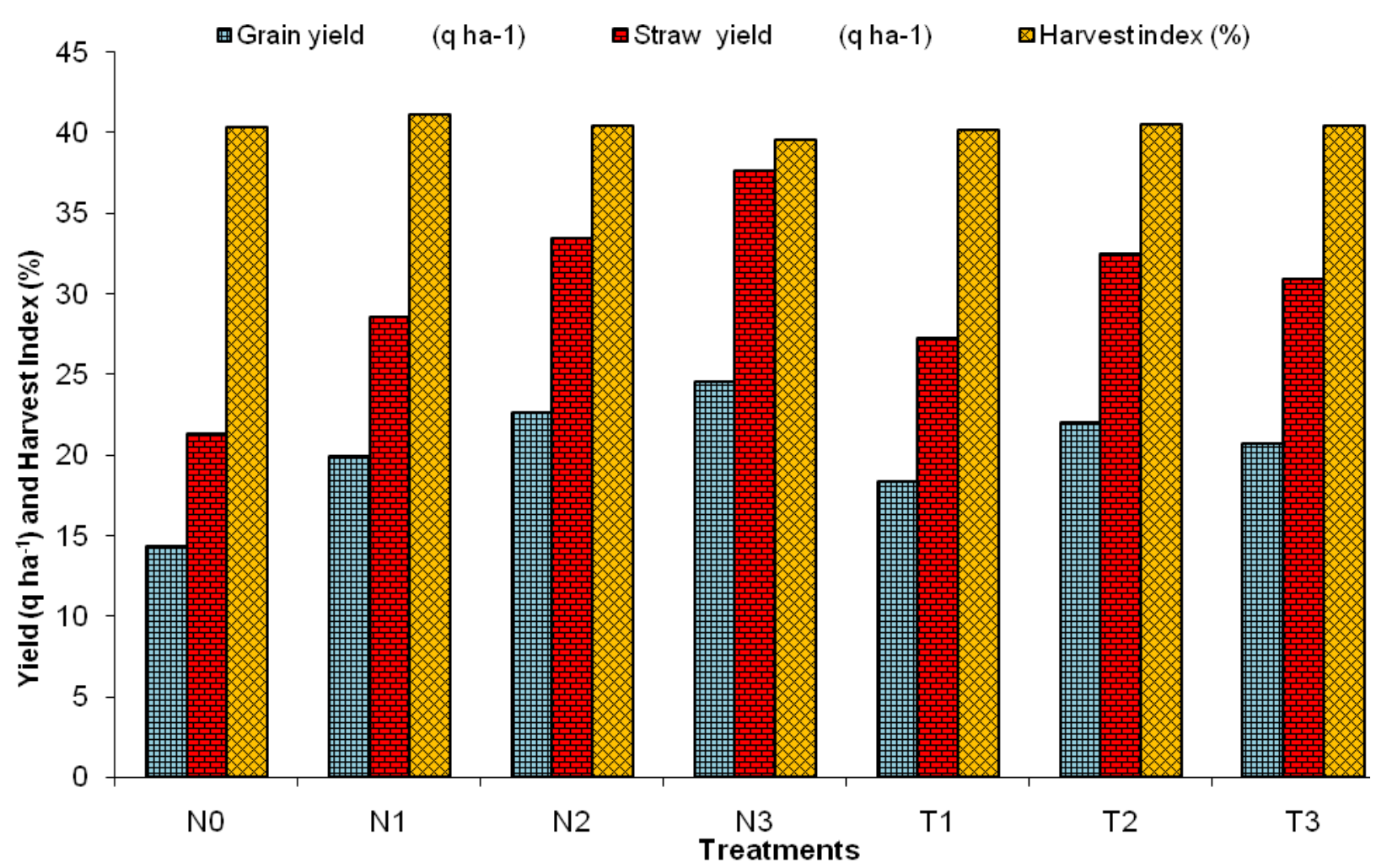

Fig. 2: Effect of nitrogen levels and its time of application on grain yield, straw yield and harvest index 
The data presented in Table 3 revealed that the cost of cultivation varied with nitrogen levels and time of application. The highest cost of cultivation (Rs. $22691.12 \mathrm{ha}^{-1}$ ) was recorded with treatment combination $\mathrm{N}_{3} \mathrm{~T}_{3}$ followed by $\mathrm{N}_{3} \mathrm{~T}_{2}$ (Rs. 22591.12) while the lowest cost of cultivation (Rs. $21530.29 \mathrm{ha}^{-1}$ ) was noted with treatment where nitrogen was not given (control). The data on grass return calculated under various nitrogen levels and its time of application presented in Table 3 showed that the maximum gross return (Rs. $46185 \mathrm{ha}^{-1}$ ) was recorded with the treatment combination where $60 \mathrm{~kg} \mathrm{~N}^{-1}$ applied as $1 / 3$ at sowing and $2 / 3$ after first irrigation followed by Rs. $42528 \mathrm{ha}^{-1}$ from the treatment where $60 \mathrm{~kg} \mathrm{~N} \mathrm{ha}^{-1}$ applied as $1 / 3$ at sowing and $1 / 3$ after first irrigation and $1 / 3$ after second irrigation. The minimum gross return (Rs. $24255 \mathrm{ha}^{-1}$ ) was obtained where $0 \mathrm{~kg} \mathrm{~N}$ $\mathrm{ha}^{-1}$ was applied. The maximum net return (Rs. $23593.88 \mathrm{ha}^{-1}$ ) was recorded when $60 \mathrm{~kg}$ $\mathrm{N} \mathrm{ha}^{-1}$ applied as $1 / 3$ at sowing and $2 / 3$ after first irrigation. The lowest net return (Rs $2724.71 \mathrm{ha}^{-1}$ ) was recorded under the treatment of $0 \mathrm{~kg} \mathrm{~N} \mathrm{ha}{ }^{-1}$. The data further revealed that the highest benefit-cost ratio (1.04) was obtained under the treatment combination of $60 \mathrm{~kg} \mathrm{~N} \mathrm{ha}^{-1}$ with $\mathrm{T}_{2}$ treatment (1/3 at sowing and $2 / 3$ after first irrigation) followed by (0.87) $\mathrm{N}_{3} \mathrm{~T}_{3}$ treatment. The lowest benefit-cost ratio $(0.12)$ was observed with the treatment of $0 \mathrm{~kg} \mathrm{~N} \mathrm{ha}^{-1}$. The highest gross return of Rs $46185 \mathrm{ha}^{-1}$ was obtained in $\mathrm{N}_{3} \mathrm{~T}_{2}$ treatment where $60 \mathrm{~kg} \mathrm{~N} \mathrm{ha}{ }^{-1}$ was applied as $1 / 3$ at the time of sowing and $2 / 3$ after first irrigation followed by Rs. 42528 ha $^{-1}$ under $\mathrm{N}_{3} \mathrm{~T}_{3}$ treatment where $60 \mathrm{~kg} \mathrm{~N}$ was applied as $1 / 3$ at the time of sowing and $1 / 3$ after first irrigation and $1 / 3$ after second irrigation due to maximum grain and straw yield. The lowest gross return Rs $24255 \mathrm{ha}^{-1}$ was recorded in $0 \mathrm{~kg} \mathrm{~N} \mathrm{ha}{ }^{-1}$ due to lowest yields. Maximum cost of cultivation Rs. $22691.12 \mathrm{ha}^{-1}$ was recorded under $\mathrm{N}_{3} \mathrm{~T}_{3}$ followed by $\mathrm{N}_{3} \mathrm{~T}_{2}$ and $\mathrm{N}_{3} \mathrm{~T}_{1}$, respectively.
Highest net return of Rs $23593.88 \mathrm{ha}^{-1}$ was recorded in $\mathrm{N}_{3} \mathrm{~T}_{2}$ followed by Rs 19836.88 ha $^{-1}$ in $\mathrm{N}_{3} \mathrm{~T}_{3}$ treatment. The lowest net return of Rs. $2724.71 \mathrm{ha}^{-1}$ was recorded in $0 \mathrm{~kg} \mathrm{~N}$ $\mathrm{ha}^{-1}$ due to lowest gross return. Maximum benefit cost ratio Rs. 1.04 was recorded in $\mathrm{N}_{3} \mathrm{~T}_{2}$ treatment, where $60 \mathrm{~kg} \mathrm{~N} \mathrm{ha}{ }^{-1}$ was applied followed by Rs. 0.87 in $\mathrm{N}_{3} \mathrm{~T}_{3}$ treatment. Maximum cost of cultivation of Rs $22691.12 \mathrm{ha}^{-1}$ was recorded under each in $\mathrm{N}_{3} \mathrm{~T}_{3}(1 / 3$ at time of sowing and $1 / 3$ after first irrigation and $1 / 3$ after second irrigation) and $\mathrm{N}_{3} \mathrm{~T}_{2}$ (1/3 at the time of sowing and $2 / 3$ after first irrigation) treatment combinations. Maximum gross return Rs $46185 \mathrm{ha}^{-1}$ was recorded with $\mathrm{N}_{3} \mathrm{~T}_{2}$ treatment combination where $60 \mathrm{~kg} \mathrm{~N}$ ha $^{-1}$ was applied as $1 / 3$ at the time of sowing and $2 / 3$ after first irrigation. Highest net return of Rs $23593.88 \mathrm{ha}^{-1}$ was recorded in $\mathrm{N}_{3} \mathrm{~T}_{2}$ followed by Rs. 19836.88 ha $^{-1}$ in $\mathrm{N}_{3} \mathrm{~T}_{3}$ treatment combinations. The benefit cost ratio (Rs. 1.04) was observed maximum under the treatment combination of $\mathrm{N}_{3} \mathrm{~T}_{2}$ followed by (Rs. 0.87) $\mathrm{N}_{3} \mathrm{~T}_{3}$ treatment combination.

On the basis of result of the experiment, it may be concluded that a dose of $60 \mathrm{~kg} \mathrm{~N} \mathrm{ha}^{-1}$ seems to be suitable for yield and quality of late sown barley and application of $60 \mathrm{~kg}$ nitrogen in two split application i.e. 1/3 at the time of sowing and $2 / 3$ after first irrigation proved to be more remunerative and economical.

\section{References}

Abrmova, G. K., Koroleva, R.O. 1974. Effect of mineral fertilizer on grain yield and sowing quality of seeds barely, F.C.A., 27 (9).

Anonymous 2013. Barley Network Progress Report 2012-13. All India Co-ordinated Wheat and Barley Improvement Project. DWR, Karnal, p-1.1

Birchet, C.J., Fukai, S and Broad, I.J. 1997. 
Estimation of response of yield and grain protein concentration of malting barley to nitrogen, irrigated malting barley. Commun. Sci. Plant Anal., 18: 433-444.

Biswas, S.K. and Singh, K.N. 1982. Nitrogen management in barley and wheat on yield attributes and economics production. Indian J. Agron., 30 (4): 488-496.

Dwivedi, D.P.; Pal Hari and Kumar, M. (1987). Response of barley varieties to nitrogen under irrigated conditions. Ind. J. of Agron. 32 (2): 189-190.

Kahnt, G.1. and E. Kubler. 1981. Influence of sowing date, sowing rate and increasing $\mathrm{N}$ rates on yield of various cereals. 1st contribution: winter barley. Bayerisches Land wirtschafiliches Jahrbuch. 58(3): 333-346.

Kerich, G.C. and Halloran, G.M. 1996. Nitrogen fertilizer effects on the duration of the per-anthesis period and spikelet number per spike in barley. $\mathrm{J}$. of Agron. and Crop Science 177 (5) : 289-293.

Kotrba, L., L. Ludva and V. Pokorny. 1984. Effect of sowing date and nitrogen fertilizer application interaction on yield formation in spring barley. Rostlinna Vyroba. 30(1): 43-51.
Nagrajan, S. 1992-93. Barley agronomic trait, levels of fertilizer varieties. Annual Progress Report of Barley Network Research Centers (ICAR) 4.1, 4.23.

Noworolink, K. 1990. Response of winter barley to soil condition, $\mathrm{N}$ application, sowing date and sowing rate Reokijajeczmicniaozimogo Panitnik Putausaski (1989). Publ. No. 94: 237244.

Singh K.; Ramesh and Singh, R. K. 2005. Effect of time and levels of nitrogen application on malt barley (Hordeumvulgare). Indian journal of Agronomy 50 (5): 137-139.

Singh, C.; Gurwal, H.B. and Katti, G.B. 1968. Effect of placement of fertilizer and its level on wheat under barani condition in black cotton soil of M.P. Indian J. Agron.,13 (1): 64-68.

Singh, J. and Singh, A. 2013. Productivity and quality of malt barley (Hordeumvulgare) as affected by sowing date, rate and stage of nitrogen application. Indian Journal of Agronomy; 58(1):72-80.

Singh, K.N. and Bains, S.S. 1969. Exploit your high water table through fertilizer use. Indian Farming, 19(4).

\section{How to cite this article:}

Srimannarayan Dubey, Ankit Tiwari, Vivek Singh, Vinay Kumar Pandey and Ghanshyam Singh. 2018. Effect of Nitrogen Levels and Its Time of Application on Yield Attributes, Yield and Economics of Barley (Hordeum vulgare L.). Int.J.Curr.Microbiol.App.Sci. 7(01): 16951705. doi: https://doi.org/10.20546/ijcmas.2018.701.205 